\title{
LOCAL ECONOMIC DEVELOPMENT IN THEORIES OF REGIONAL ECONOMIES AND RURAL STUDIES
}

\author{
Bahrija Kačar' ${ }^{\text {, Jasmina Curič², Selma Ikič }}$
}

\begin{abstract}
Summary
In this paper is a detailed analysis of the basics in the theory of economic development during the period from mid last century until today. It states the most significant theories, points out their ranges, offers a critical review regarding their treatment of development, especially regional, rural and local one. It observes those theories according to different classifications existing in scientific literature, primarily the ascend theory, stagnation theory, balanced economic growth theory; then, short-term and long-term development and growth theories; traditional and endogenous theories; economic growth stages theory emphasized after the WW II; structural changes theory; dependency theory, neo-classic counter-revolution theory and endogenous theory as a new growth theory. The analysis becomes wider with a study on development in regional economy theories and rural studies and it systematizes the classification of those theories according to regional economy academics. Distancing ourselves from any particular division as the most suitable and acceptable one, the theories are treated separately and in an historic context, in order to encircle the time framework which from modern theories, dealing with local level development difficulties, resulted. It asserts The Community-led Rural Development Theory, often referred to as the Community Development Theory, or marked as Bottom-up Partnership Approach. The analysis of development theories asserts that mixed exogenous - endogenous approach to development links the rural/local development to the globalization process mostly due to fast technology changes of the IT and communication sectors.
\end{abstract}

Key Words: economic growth, local economic growth and development, exogenous, endogenous and exogenous - endogenous development

JEL: $Q 10, R 11,013$

1 Bahrija Kačar, Ph.D., Assistant Professor, University of Novi Pazar, Department for Economic sciences, Vuka Karadžića nn, 36300 Novi Pazar, Serbia, Phone: +381 62333 808, E-mail: bahrijakacarnp@yahoo.com

2 Jasmina Curić, Ph.D., Assistant, University of Novi Pazar, Department for Chemical Technological sciences, VukaKaradžićann, 36300 Novi Pazar, Serbia, Phone: +381 6663 15 270, E-mail: jasminacuric65@gmail.com

3 Selma Ikić, M.A., Assistant, Office for local economic development, City administration of Novi Pazar, Stevan Nemanja Street no. 2, 36300 Novi Pazar, Serbia, Phone: +381 62488 740, E-mail: selma.ikic@novipazar.org.rs

EP 2016 (63) 1 (231-246) 


\section{Introduction}

The topic this analysis deals with is complex and refers to local economic development in the theories of regional economies and rural studies. Local economic development is composite and complex area that, in addition to economic development policy including agriculture, also incorporates other divisional, structural and social policies, local infrastructural development policy, as an indispensible ambience for local economic development, as well as all sorts of civic initiatives contributing to local communities' improvement. The first part of the analysis shows a short review of economic theories of both rural and local areas. As far as they are concerned, the first part briefly examines Regional development theories, Traditional models of regional economic development, Pure agglomeration models of regional economic development, Models of local community regional economic development and Models of regional economic development territorial novelties. The second part illustrates the historic context of the theories. Economic scholars started studying economic growth following the disintegration of the colonial system and creation of independent states.

\section{Methods to be applied}

The paper is primarily used qualitative analysis that is necessary extent and scope supported by quantitative analysis where it was for the space and needs. In examining the phenomenon used the method of analysis, while in the process of concluding and finding solutions used method of synthesis. Basically, have been used as inductive and deductive method of scientific analysis and synthesis. Where it was necessary, we used historical method and scientific monitoring and reasoning as well as the comparative method.

\section{Economic theories of rural and local areas}

Rural, and particularly local, development could be observed through the regional economy prism as well as from a point of view of multidiscipline rural studies, and not only trough basic economic development theories. By comparing these two segments regarding economic development of rural and local areas, it can be said that rural studies are dealing more with organizational aspects of rural economy, while the regional economy scholars are more concerned with combined effects of production, labor and capital, as well as with other factors that often influence them. In case when development theories within rural studies implicitly assume accessibility of the production, labor and capital factors, these theories do not differ much from the regional economy field theories. It could actually be said that, regardless of different terminology and different specialists, a certain overlap of these theories appears in Table 1. 
Table 1: Matching of development theories within regional economy

\begin{tabular}{|l|l|l|}
\hline Exogenous development theories & $\rightarrow \rightarrow \rightarrow \rightarrow$ & Pure agglomeration models \\
\hline $\begin{array}{l}\text { Local community stimulated development } \\
\text { Brayden stationary resources theory }\end{array}$ & $\rightarrow \rightarrow \rightarrow \rightarrow$ & Local community theories \\
\hline Exogenous-endogenous development theories & $\rightarrow \rightarrow \rightarrow \rightarrow$ & Territorial innovations theories \\
\hline
\end{tabular}

Source: Terluin, 2013.

The growth pole theory links the exogenous development theories to the Pure agglomeration models, while local regions factors link the endogenous development theories to local community ones. Although the concept of innovations has not been mentioned explicitly in the combined development exogenous-endogenous theories, it is obvious that the economic dynamic is a consequence of mutual influence of both local and external factors, where, among other things, innovations exchange. Thus, these theories could be linked to the territorial innovations theories.

In chronological presentation, the theories are offered mostly according to the rural study scholars' viewpoints, so that herein the regional economists' development theories will be only briefly commented. The regional economists' analysis consist of two dominant viewpoints, spatial-economic models based on neoclassic assumptions, and institutional perspectives of regional economic development in which the complex networks of social, cultural, political and historic regional factors are embedded (Boekema et al., 2000).

\section{Regional Economic Development Theories}

The case study of the regional economy can be divided into macro-economic and micro-economic aspect. Regional macroeconomics mainly analyzes the comparative economic characteristics of the different regions within the national economy. Regional macroeconomics deals with issues involving comparative economic growth, variations in employment levels between the region and the movement of production factors between regions. In terms of regional macroeconomics developed some econometric models that are essentially similar models of national economies. Instead of mutual relations between the different countries they give attention to the mutual relations between the regions. There are various specifications of theories and models of regional development. Basically, we can distinguish between at least four classifications are listed in Table 2.

Unlike regional macroeconomics, microeconomics more regional deals with the problem of location and interaction of specific economic activities. It discusses the impact of space and distance to economic activity and is not engaged in the region as a homogenous unit. The subject of regional microeconomics deals with the theory of location. The term spatial economy is sometimes used as a synonym for the regional economy, although in that event the emphasis on the significance of space and distance more micro than the macro aspects. Regional economy, especially its macro aspect, was developed largely as an applied analysis and its growth reflects the political concern 
about regional differences and economic success of various regions.

The first theory based location set by German theorist's locations, Heinrich von Thünen (1826), which explored the relationship rents, prices of agricultural products and the distance of the market. But generally considered to be the founder of the theory of location Alfred Weber (1868-1958) according to whose theory the main location factors considered: (a) transportation costs, (b) labor costs and (c) agglomerative-deglomerative factors. In the literature it is known the so-called. "Weber's locational triangle", which seeks to determine the optimal location of production due to the spatial accommodation of raw materials, labor and markets selling.

The common item in a number of regional economy scholars' theories definitely is a focus on explaining the production growth in a region. Table 2 shows that the production in a region is directly linked to its industrial competitiveness. Since regional economic development theories conceptualize in different ways the regional industrial competitiveness, herein the criteria for the classification of theories is the relation between the companies' competitiveness and regional production, expressed in the production function $Y=f(X, W, Z)$.

Depending on what factors are included into the production function, the regional economic development theories can be divided in for main groups: Traditional models, Pure agglomeration models, Local milieu models and Territorial innovation models (Terluin et al., 2003). The order of these models is made in accordance with the production function factors' growing complexity. Table 2, illustrates the classification and basic regional economists' theory methods.

Table 2: Classification of theories according to regional economy scholars

\begin{tabular}{|l|l|l|}
\hline & Production function* & \multicolumn{1}{|c|}{ Theories } \\
\hline Traditional models & $Y=f(L, K)$ & $\begin{array}{l}\text { Neo-classic growth theory } \\
\text { Keyne's approach: export theory base }\end{array}$ \\
\hline Pure agglomeration models & $Y=f(A E, L, K)$ & $\begin{array}{l}\text { Cumulative causation theory } \\
\text { Growth pole theories } \\
\text { New economic geography theories }\end{array}$ \\
\hline Local community models & $Y=f(L M, L, K)$ & $\begin{array}{l}\text { Endogenous growth theories theory } \\
\text { Theories based on labor organizational } \\
\text { changes }\end{array}$ \\
\hline Territorial inovation models & $Y=f(I, L M, L, K)$ & $\begin{array}{l}\text { Incubator theories } \\
\text { Products' life cycle theories } \\
\text { Innovative environment theories } \\
\text { Porter's national competitive advantage } \\
\text { theory } \\
\text { Ilery's induction regional development } \\
\text { theory } \\
\text { Storper's theory on regions as a chain of } \\
\text { non-exchanged interdependence }\end{array}$ \\
\hline
\end{tabular}

*Y: production; L: labor; K: capital; AE: agglomeration effects, which occur due to external 
factors or volume economy; LM: local milieu which means factors such as space, human capital, technology, networks, culture, politics etc.; I: innovation.

Source: Terluin, 2003.

\section{Regional Economic Development Traditional Models}

The first group of the regional economic development theories, herein marked as traditional models, assumes that the production presents the function of labor and capital entry. Main representatives of this theory group are neo-classic theories of growth and theories of export basis. Neo-classic growth theories say that the decrease of regional differences depends on availability and inter-regional mobility of the production, capital and labor factors. Since the production functions are identical, capital tends to move into the regions with cheap workforce, while the workforce will take the opposite direction. These trends will continue until the return of capital and laborers' salaries become identical in all regions. Developing the neoclassical growth theory greatest contribution was given by Robert Solow and Trevor Swan.

The export base theory splits economic activities into those producing for exports and non-basic activities producing for internal use. The growth in basic activities is conditioned with money flows in a region, it increases demand for goods and services inside the region and causes a raise of non-basic activities volume.

\section{Pure Agglomeration Models of Regional Economic Development}

In the second group of prominent theories of pure agglomeration models, production depends on labor and capital concentration in a particular place which leads to the external economy volume effects. For example, the basic idea of the growth pole theories is the existance of an initiator - operating company that acts as a pillar and stimulates the growth of other industries and businesses through a multiplicator effect. The most famous representative of the theory of growth poles were Francois Perroux and Hirschman Friedman.

Main assumtion in the theory of cumulative causation, the second group within agglomeration models is that once the regional differences occur, a self-reinforcing process starts and, unless there are catastrophic events, it maintains the growing areas status. The agglomeration of economic activities and people further expands the rich regions. This widening of production results leads to migrations (often of highly qualified workforce) from areas that are lagging behind into developed regions. This cumulative process of concentration and expansion of economic activities in rich regions has a number of harmful consequences for the so-called lagging behind regions: they are deprived of workforce and capital. The largest contribution to the development of the theory of cumulative effects gave Gunnar Myrdal.

One of recent opinion in this theory group of pure agglomeration models is "new economic geography" (NEG). Usually, NEG models assume two economy sectors - agriculture and industry. NEG, studies spatial population concentration and / or 
economic activities in conditions that lead to an increased return to the volume economy and a monopole competitiveness (Fujita et al., 1999). According to this theory, already big domestic market can cause further cumulative process of attracting companies and labor. Changes in industrial clusters' concentration location can occur due to amended transport costs. Development of the theory of economic geography given by Paul Krugman and Masuhita Fujita.

\section{Local Milieu Models of Regional Economic Development}

Local milieu (environment) theories stipulate that different factors, such as workforce ability, technical and organizational knowledge, social and institutional structures, influence both capital and work incomes. The most important representatives of the local community models and theories of endogenous development are Romero (1986-1990), Lucas (1988), Grossman and Helpman (1991). The difference between endogenous growth models and theories of growth occurs as a result of changes in work organization. Endogenous growth models and development usually refer to areas surrounding cities, but are not well connected to a city. Industrial district model is an example of such type of theories. In that system, the agglomeration of small and mid-size companies exchanges semi-finished products what can be described as a collective production process. The relations between enterprises and people in a local system are not determined by regulations only, but largely depend on local rules and customs rooted into tradition and culture of that region. (Iacoponi et al., 1995). The other kind of premises in local milieu theories is development theory based on labor organizational changes. Starting assumption in this theory is that the workforce structure in a sense of skills, costs, mobility, numbers and alike, varies from region to region. Those differences in workforce can influence a decision on a company location: areas with conditions for profitable production attract investments, while the lack of them takes place in areas where possibilities for profitable productions were exhausted.

\section{Territorial Innovations Models In Regional Economic Development}

According to the fourth group of regional economy theory, in addition to labor and capital, an important factor of growth and development of a local milieu is the diffusion of innovations. An innovation herein should be understood in a wider context. It includes products', processes' and organizational innovations, as well as social and institutional innovations at a level of industry, region and nation (Morgan, 1997, p. 492). Stressing innovation implicates that technical possibility of an adjustment to innovations is crucial for winning over new types of production and entering new markets. Different theories, such as incubators theories, product's life cycle, innovation-surrounding theory, Porter's national competitive advantage theory, Ilery's induction regional development theory) and other belong to this group.

\section{The Development Of The Theory Of Regional Economic Development}

Table 2. Depending on which factors are involved in the production function theory, regional economic development are divided into four main groups: the traditional 
models, pure agglomeration models, local communities and models of territorial innovation. Depending on the current problems by theorists at that time studied and gave them important while neglecting and excluding certain important factors of development of the production function. Representatives of the local community model of the production function $Y=f(L M, L, K)$ excluded factor of agglomeration effect (AE) that were previously represented by representatives of the clean agglomeration models in its function $Y=f(A E, L, K)$. Representatives of territorial innovation models that expand the production function model of the local community by adding a factor (I-innovation), but they do not take into consideration factors of agglomeration effect in its production function $\mathrm{Y}=\mathrm{f}(\mathrm{I}, \mathrm{LM}, \mathrm{L}, \mathrm{K})$. Recruitment of the production function and factor of agglomeration effects get production function ( $\mathrm{Y}=\mathrm{f}$ (I, LM, $\mathrm{L}, \mathrm{K}, \mathrm{AE}$ ), which is more comprehensive. One of the deputies OVG model at this time would represent theorists endogenous - exogenous model of regional economic development.

Future development of the theory of regional economic development would go in the direction of the endogenous-exogenous economic and institutional development. That the endogenous-exogenous regional development will increasingly developed through various institutional forms. Institutional development and institutional connections will depend on the state system, the state of development of both the level and the local level.

\section{Regional Economic Development Theories In Historical Context}

Economic scholars and economic policies creators start studying economy development process, aiming at creating successful economic strategies and development policies only after the decomposition of the colonialism and creation of independent states. Deliberation of independent development of less developed countries, i.e. economic and social aspects of the third world countries, was not an aim of the developed, while the underdeveloped countries had no capacity of their own.

In the 1940s and 1950s, an economic war became a main goal of newly founded states' economic policies. It was consider that the economic warfare and modernization would per se eliminate both income and social disparities. Other economic and social goals were considered corresponding, somewhere even because of the GDP growth. The acceptance of the GDP increase as an aim, and developing means to achieve growth and development, represented a conceptual base of the theories in the 1950s. The main theoretical contributions to the issue of economic development during this decade were evident in one-sector model and in pointing out investments. The most important theories and economic development concepts in 1950s are: Big push theory by Rosenstein-Rodan (1943), Balanced growth by Nurkse (1953), Rostow's Take-off into sustained growth (1956) and Critical minimum effort thesis by Leibestein (1957).

Already in the $60 \mathrm{~s}$, an analytical framework based on economic dualism aiming to explain the reciprocal roles of two sectors in development process, dominated. Two-sector model by 
A. Lewis (1954) still gave the agriculture a passive role as a potential source of "unlimited labor" and "agriculture surpluses" for a modern (industrial) sector.

In the second half of 1960 s, there was a change in development theory regarding the agriculture and its role in economic development. Instead of agriculture as a passive sector from which capital should be squeezed out for the industry expansion, a conclusion was that the agriculture could contribute more as an industry partner in a role of resources provider. In early development phases, it can generate the rise in agriculture production and productivity what, in turn, eases the transfer back from agriculture into a modern, industrial sector (Trobecke E., 2006). Johanston B. and Mellor. J (1961) both ascertain that a powerful and dynamic agriculture sector is a key factor for industry improvement and for achieving national economy's fast growth rate.

After this period, in 1970s, the failure of growth strategies based on GDP led to a thorough screening of economic and social development process. Main development problems that became acute, and could not be ignored in this decade, can be summarized in the following way: (i) increase in unemployment and increase in awareness of unemployment, (ii) unequal income distribution tendency within a country (as it was the case immediately after the WW II); (iii) large number of poor people who lived beyond the poverty line; (iv) continuation and acceleration of rural-urban migrations with urban congestion as its result, and, finally (v) worsening of external position of developing countries. Mostly due to the consequences of these problems, developing countries tried harder to solve them requiring equal distribution of wealth in order to lessen the rate of absolute poverty in relation to an economic growth regarded per se as an aim. Besides, this lessening of absolute poverty should be achieved mostly through productive employment in traditional sectors.

By mid 70s, GDP, as a dominant overall goal, was largely rejected. The assumption that a total growth was a synonym for both economic and social development, and alternatively, that it would secure the achievement of other development aims, came under scrutiny and critics check and rebuffed by many circles. The launch of World employment programme in 1969, signaled that a primary goal must be linked to the increase of living standard of the poor through employment boost (Thorbecke E., 2006).

The change in understanding development as a process that has economic growth and reduce of poverty at the same time as its goals influenced a number of conceptual and empirical inputs. The first set of inputs can be called the integrated rural and agricultural development. Two versions of a strategy oriented towards distribution surfacing in these two decades overlapped partially. Those were theory of redistribution with growth and basic needs theory. First theory is basically of an incremental nature, resting on existing distribution of means and factors and demanding increased investments into project transfers (mostly public, but maybe even into private) for the benefit of the poor (Cheneri et al., 1974). Second alternative strategy in 1970s was basic needs strategy. It suggests structural changes and redistribution of the initial property ownership, particularly land reform together with set of policy instruments such as public investments. Basic needs are defined by two elements: (i) a family minimal demands for private spending for appropriate 
nutrition, accommodation and clothing and (ii) basic services for community as a whole, such as drinking water, sewerage system, health and educational institutions. An integrated rural development is a complementary policy in the agriculture sector. In short, new approach aims at crediting and technically equipping traditional sectors directly. The name of this strategy is unimodal strategy of agricultural development (Johnston and Kilby, 1975). Third type development strategy emerges from neo-Marxist theory of underdevelopment and dependence. This approach was radical, if not revolutionary in its nature. It called for huge redistributions of capital and abolishment a majority of private ownership. NeoMarxist, as well as structural studies of agricultural development, all say that traditional agriculture is neither stationary nor effective, and that the allocation of recourses cannot be separated from either the wealth distribution or the production organization. They also say that efficiency does not necessarily follows the realized surpluses, that the social relations in production can inhibit the accumulation and determine the shape of technological changes. In addition, they stress that the role of a state as a coercion factor in the primitive accumulation is primarily economic and not political.

According to the Marxist apprehensions, rural areas have no possibilities for endogenous development, since they are oppressed and inactive. Pre-capitalist rural economy was categorized by self-sufficiency. According to the Marxist apprehensions, the influence of industrial development on rural areas leads to the replacement of self-sufficient production by export-oriented agricultural production and the substitution of imported goods of mass production with local manufacture products. These changes stress out the exogenous nature of an economic development process. In connection with that, Lipton (1977) develops a concept of rural bias in the economic development process. He, as some other authors, has previously noted the existence of spatial differences or inequality at the poverty level, i.e. well-being, between urban and rural areas. Its consequence is a conflict between rural and urban regions emphasized by poor countries, which again indicated the reality of the conflict existing in theory between capital and workforce, and between domestic and international interests.

In the 80 s, extremely heavy burden of the external debt that represents a cumulative effect of a decade-long borrowing and manifests itself in a huge budget and payments deficit in the majority developing countries coupled with higher interest rates and recession in creditor countries, has radically changed development and aid from environs. Achieving foreign trade balance became dominant goal and one of basic conditions of economic growth and development. Mexican economic crisis in 1982, spread quickly to other parts of the socalled third world. The crisis was so big that it, at least for some time, put at risk the survival of international financial system (Thorbecke et al., 2006). Due to that, the beginning of the $80 \mathrm{~s}$ is characterized by skepticism regarding the efficiency of conventional development policy instruments. Exogenous approaches to rural development were disapproved of because they advocated the following: independent development but still conditioned by financial aid and the decisions by distant agencies and other executive bodies; then, uneven development that encouraged the expansion of individual sectors, areas and certain kinds of labor, and neglected non-economic aspects of rural life. There is also the so-called 
destructive development that overlooked cultural and differences in rural area environment, as well as dictated development which external experts and planners suggested (Lowe et al., 1999).

In the 80 s, these difficulties led to a change towards the so-called rural areas endogenous development theories. They were based on a viewpoint that specific recourses of an areanatural, human and cultural - are key factors for sustainable development of that area (Ploeg et al., 1995). According to this concept, human capital helps technical progress becoming internal development factor partly, instead being dominantly external one. Cited sources for this concept are: (i) permanent innovations and investment into research and development and (ii) diffusion of knowledge and transfer oh know-how (Thorbecke et al., 2006).

According to Ray (1977), there are three basic characteristics of endogenous development. Firstly, development activities are practiced in respect of territorial, and not sector principle, whereby the theories are less nationally determined. Secondly, economic and other development activities are reoriented in a way to maximize the return of profit into local area limits by means of evaluation and usage of local resources - material and human. Thirdly, the development is formulated with an accent to needs, capacities and possibilities of local population, what means that local area should develop capacities for undertaking some responsibilities regarding their social-economic success. "Working partnership" collaborative agreements between public bodies, or between public, private and volunteer sectors, are recognized as a mechanism of inception and management of the endogenous economic development concept.

The second set of theories links growth and development to trade, more specifically to foreign trade orientation of a country. The countries that liberalize and encourage the trade are growing faster since in addition to trading goods the transfer of technology happens as well. The acceptance of innovative technologies contributes to human capital expansion what in turn helps development concrete as well as other economic sectors.

Yet another set of contributions could be called "new institutional economy". A focus on strategic behavior of both individuals and organizations inside an imperfect market represents the highest progress. The theories of imperfect and asymmetric information, or broadly speaking, transaction costs, secure logical explanation for existence of institutions as instruments for reduction of transaction costs.

The estimation could be that in the 80s liberal approaches to development theories were mostly present.

In the first half of the 90s, stabilization and adjustment remained as dominant goals. Developing countries ever more clearly saw that crucial and radical institutional changes that will reduce corruption and enable successful transition towards market economy are precondition for the successful transition process and adjustment to new business conditions.

Probably the most important issues in the 90s are the role of a state and the role of a market in development process, and in connection to that, identification of most commendable institutions for speeding up the economic growth process and social-economic development. 
In many aspects, development strategy in the first half of the $90 \mathrm{~s}$ was built on the foundation of theories from the last decade and was made of the most of their strategic elements. However, as the time went by, two new opposite standpoints about the adjustment theory and its influence on development process appeared. The World Bank is the most vehement advocate of the first standpoint known as orthodox view. Its basic postulate is that a timely package of stabilization and adjustment measures is worthwhile. Countries that have progressed in implementing this package made a turn regarding growth rate and other indicators of economic growth and development. Opposite to this approach, there is heterodox approach- best explained trough the concept of "adjustment with a human face". UNICEF advocates it. This concept supports the need for adjustment, but, it points out that the approach backed by the World Bank achieves short-time stabilization and that this concept does not effectively influence the deeply rooted structural economy shortages that are a main reason for macroeconomic instability and economic stagnation.

It should be stressed that in the 90s many scholars promoted endogenous development approach. It can be interpreted as a local development, mostly derived from local impulses and mostly based on local recourses (Picchi et al., 1994; Terluin et al., 2003). Unlike in exogenous models, the development advantages remain within local economy, and local values are respected (Slee et al., 1994; Terluin et al., 2003). Three specific rural development theories within this approach are: rural development adjusted to rural community theory; theory of property potentials to create a competitive advantage in rural community and a community development model through creative destruction.

Finally, there is the community-led rural development theory, so named by Murray and Dunn, 1995. It focuses on strengthening development capacity of local communities themselves. Such theoretical approach is found in standpoints of Keane and Cinneide who in 1986 named it the Community development theory, also known as bottom-up partnership approach, which Mannion in 1996 used to mark this theory.

Institutional structures' partnerships and adjustments are seen as main way in the process of building these capacities. Institutional adjustment is of a particular importance because of linkage between local, regional and national authorities since this type of development demands institutional structure that encourages and responds to the initiatives by "bottomup" principle.

In connection with that, in 1998 Bryden points out in his theory that the increase of capital mobility, trained workforce, information and other goods and services are not a firstrate basis for creating a rural development strategy. Instead, Bryden suggests that rural areas' advantages should be based on stationary resources that cannot be compared and contended. According to this theory, there are four types of stationary resources: social capital, cultural capital, environment as capital and the capital of local knowledge and skills. Economic development of rural areas will depend, according to Bryden, on the combination of tangible / material and non-material stationary resources, as well as on the way of their mutual relations in a local context (Turluin, 2003). 
In 1998, the next concept, the model of community development through destruction that Mitchell wrote about refers to the usage of a village idyll for local economic development. This approach was successfully implemented in creating tourist destinations marked as heritage shopping villages. Examples of such places are Nelson and St. Jacobs in Canada and Abarracin in Spain. This rural development theory assumes that the expansion of traditional villages is based on a mutual relation among three variables: entrepreneurial investments, usage of rural heritage and the destruction of rural idyll. Basic idea of this theory is that the entrepreneurial sale and rural heritage marketing bring in / lure modern consumers in search for nostalgic return to their rural roots. The result of rural heritage spending provides the entrepreneurs profit for re-investment in this tourist destination. This can lead to a cumulative process of an increase in rural heritage spending and new investments. After some time, an overexploitation and the destruction of rural idyll happen.

At the beginning of XXI century, an opinion was that the economic development scholars ran out of "big ideas". The most important contribution to the development doctrines in this decade is not merely theoretical, but also methodological. It is about the usage of random and controlled experiments to evaluate development policy efficiency. Controlled experiments have not lightened up the basic mechanism that leads to successful results. Main objections to this methodology are: 1) simplification of the model that does not explicitly point out the structure of the model and making this adjusted form to omit the given hypothesis, and 2) a total negligence of the economical intervention effects to achieve a general balance. Despite these shortcomings, this methodology contributed in creating a big number of excellent empirical studies (Thorbecke, 2006).

New political economy points out the role of investments in economic growth theory. One of its main principles is that equal distribution of initial income and wealth leads to an economic growth. This new approach is totally opposite to a classic stand which says that an unequal distribution of income is a pre-condition to growth based on an understanding that the rich / capitalists save more of their income than the poor / workers.

A key question is linked to an evaluation of the present form of globalization / integration and their benefits for the economic growth process that unites economic growth, leads to the reduce of poverty and creates positive distributive effects. That is why it is said that mixed exogenous-endogenous approach to development links rural development to the process of globalization, mostly due to fast technological changes within the IT and communication sectors. Therefore, according to this theory, rural development consists of a complicated and knotty network of relations in which resources are mobilized and in which process control is made of mutual act by local and external powers / factors (Terluin, 2003).

According to the opinion of certain authors (e.g. Lowe et al., 2002; Durand, Huylenbroeck, 2002) "multi-functionality" could also be considered as a way to achieve rural development. This opinion contradicts the approaches of liberal scholars, as well as those of interventionists. The multi-functionality theory differs from other modern rural development theories, such as a network approach, since its basic both mean and goal are the expansion of agriculture and farming enterprises. 


\section{Conclusion}

Based on a complete argumentation that was stated in a complex approach to its realization, it is fair to conclude that contrary to theories oriented onto the GDP growth with development polarization as its consequence, after the 1970s, a new detailed questioning of economic and social development took place. Main development problems became acute and could not be ignored any more. Thus, the meaning of a development as a process that simultaneously has economic growth and reduction of poverty as its goals has changed. That has influenced a number of both conceptual and empiric contributions. Therefore, what characterized the beginning of the $80 \mathrm{~s}$ was skepticism about the efficiency of conventional development policy's instruments, making economic scholars to start looking for dominant alternative theories of regional development. Exogenous approaches to development were criticized because they advocated an independent development yet conditioned with financial aid and the decisions by distant agencies and other executive bodies; then, an unequal development occurred, encouraging only some sectors, areas and some kinds of labor, and at the same time, a disregard of non-economic aspects of rural / local life also happened. These difficulties in the 80 s lead to a shift towards the so-called endogenous development theories based on an approach that specific resources of a region represent a key to its sustainable development. In that sense, by joining other similar opinions, a combined endogenousexogenous model is advocated as the most convenient concept for developing countries.

\section{Literature}

1. Anriquez, G., Stamoulis, K. (2007): Rural Development and Poverty Reduction: Is Agriculture Still the Key, ESA Working Paper 07-02. The Food and Agriculture Organization of the United Nations.

2. Armstrong, H., Taylor, J. (2000): Regional Economics and Policy, (3rd Edition ed.). Blackwell Publishers. Oxford.

3. Atkinson, G. (1997): Measuring Sustainable Development - Macroeconomics and the Environment, Edward Elgar, Cheltenhan, UK

4. Bardhan, P.K. (1993): Economics of Development and the Development of Economics, J. Economic Perspectivesn Vol. 7, No. 2, pp. 129-142.

5. Begović, B., Vacić, Z., Matković, G., Mijatović, B. (2006): Lokalni ekonomski razvoj, CLDS i SKGO, Beograd.

6. Behrman, J., Srinivasan, T. (1995): Handbook of Development Economics, North Holand, Amsterdam.

7. Brakman S., Garretsen H., Gorter J., Horst van der A., Schramm M. (2005.): New economic geography, empirics and regional policy, CPB Netherlands Bureau for Economic Policy Analysis, CPB Special Publications No. 56. available at: http:// www.cpb.nl/eng/pub/cpbreeksen/bijzonder/56/bijz56.pdf

8. Bryden, J. (2002): Rural development indicators and Diversity in the EU, Eurostat Report. 
9. Chenery, H. (1979): Structural change and Development Policy, Oxford University Press for the World Bank, Washington.

10. Cvetanović, S. (1999): Teorija i politika privrednog razvoja, Ekonomski fakultet, Niš.

11. Đorđević, S. (2007): Priručnik za moderno upravljanje lokalnim ekonomskim razvojem, SKGO, Fond za otvoreno društvo, Beograd.

12. Dragutinović, D., Filipović, M., Cvetanović, S. (2005): Teorija privrednog rasta $i$ razvoja, CID, Ekonomski fakultet, Beograd.

13. Eltis, W. (1984): The Clasical Theory of Economic Growth, The Macmillan Pres Ltd. London.

14. Fujita, M., Mori, T. (2005): Frontiers of the New Economic Geography, Discussion paper No. 27, Institute of Developing Economies, available at: http:/www.ide. go.jp/English/Publish/Dp/pdf/027 fujita.pdf

15. Herick, B. Kindleberger, Ch. (1984): Economic Development, McGraw Hill.

16. Iacoponi, L., Brunori, G., Rovai, M. (1995): Endogenous development and the agroindustrial district, In: Ploeg, J.D. van der, Dijk, G. Van (Eds.), Beyond Modernisation; the Impact of Endogenous Rural Development. Van Gorcum, Assen, pp. 28-69.

17. Illeris, S. (1993): An inductive theory of regional development, Papers in Regional Science, Vol. 72, No. 2, pp. 113-134.

18. Keane, M. J. ó Cinnéide, M. S. (1986): Promoting economic development amongst rural communities, J. Rural Studies, Vol. 2, No. 4, pp. 281-289.

19. Kolektiv autora (2002 - 2005): Multifunkcionalna poljoprivreda i ruralni razvoj u funkciji uključenja Republike Srbije u Evropsku Uniju,MINT Srbije, Novi Sad.

20. Kolektiv autora (2002 - 2005): Razvoj i strukturne promene agrarne privrede $i$ ruralnih područja,MINT Srbije, Novi Sad.

21. Lowe, P., Murdoch, J., Ward, N. (1995): Networks in rural development beyond exogenous and endogenous models. In: Ploeg, J.D. van der, Dijk, G. van (Eds.), Beyond modernisation; The impact of endogenous rural development. Van Gorcum, Assen, pp. 87-105.

22. Mankiw, G., Romer, D. and Weil, D. (1992): A contribution to the empirics of economic growth, Quarterly Journal of Economics, No. 107, pp.407-437.

23. Mannion, J. (1996): Strategies for local development in rural areas: the 'bottomup' approach, Cork, Paper for the European Conference on Rural Development 'Rural Europe-Future Perspectives', November 7-9.

24. Musgrave, R. (1973): Teorija javnih finansija, Naučna knjiga, Beograd.

25. Morgan, K. (1997): The learning region: institutions, innovation and regional renewal, J. Regional Studies Association Vol. 31, No. 5, pp.491-503.

26. Myrdal, G. (1957): Economic Theory and Under-Developed Regions, Methuen 
University Paperbacks. London.

27. Negović, B. i sar.(2006): Lokalni ekonomski razvoj, CLDS, SKGO, Beograd,

28. Picchi, A. (1994): The relations between central and local powers as context for endogenous development, In: Ploeg, J.D. van der, Long, A. (Eds.), Born from within; Practice and Perspectives of Endogenous Rural Development. Van Gorcum, Assen, pp. 195-203.

29. Ranis, G. (2004): The Evolution of Development Thinking: Theory and Policy, paper Annual World Bank Conference on Development Economics, Washington, D.C.

30. Romer, Paul M. (1990): Endogenous Technological Change, Journal of Political Economy, 1990, Vol. 98, pp.71-102.

31. Schumpeter, J. (1961): The Theory of Economic Development, a Galaxy Book, New York.

32. Slee, B. (1993): Endogeniuous Development: A Concept in Search of a Theory, Options Méditerranéennes No. 23.

33. Slee, B. (1993): Strengthening endogenous development patterns in European agriculture options, Méditerranéennes 23.

34. Slee, B. (1994): Theoretical aspects of the study of endogenous development, In: Ploeg, J.D. van der, Long, A. (Eds.), Born from within; Practice and Perspectives of Endogenous Rural Development. Van Gorcum, Assen, pp. 184-194.

35. Stiglitz, J. (1999): Economics of the Public Sector, The third edition, W.W. Norton Company, New York.

36. Storper, M. (1995): The resurgence of regional economies, ten years later: the region as a nexus of untraded interdependencies. European Urban and Rural Studies Vol. 2, No. 3.

37. Thorbecke, E. (1969): The Role of Agriculture in Economic Development, Columbia University Press: New York.

38. Thorbecke, E. (2006): The Evolution of the Development Doctrine 1950-2000, research paper No. 2006/155. World Institute for Development Economics Research. United Nations University.

39. Todaro, M. (1997): Economic Development. Longman, London and New York, p. 70.

40. Turluin, I.J. (2003): Differences in Economic Development in Rural Regions of Advanced Countries: an overview and chritical analysis of theories. J. Rural Studies 19, pp. 327-344.

41. Vasiljević Z., Subić J. (2008): Značaj bottom-up pristupa u planiranju i realizaciji lokalnih regionalnih programa ruralnog poljoprivrednog razvoja u Srbiji. Predavanje po pozivu. Tematski izbornik Savetovanja. 


\title{
LOKALNI EKONOMSKI RAZVOJ U TEORIJAMA REGIONALNE EKONOMIJE I RURALNIH STUDIJA
}

\author{
Bahrija Kačar, ${ }^{4}$ Jasmina Curić, ${ }^{5}$ Selma Ikićc
}

Rezime

U radu se detaljno analiziraju osnove teorije ekonomskog razvoja u periodu izmedju pedesetih godina prošlog veka do danas. Navode se najznačajnije teorije, ističu njihove domete, daje se kritički osvrt sa aspekta njihovog tretmana razvoja, posebno regionalnog, ruralnog i lokalnog. Posmatraju se teorije prema različitim klasifikacijama koje se mogu naći u naučnoj literaturi, pre svega, uzleta, teorije stagnacije i teorije uravnoteženog privrednog rasta; zatim, kratkoročne i dugoročne teorije razvoja i rasta; tradicionalnih i endogenih teorija; teorija etapa privrednog rasta koje su naglašavane nakon drugog svetskog rata; teoriju stukturnih promena; teorije zavisnosti, teorije neoklasične kontrarevolucije $i$ endogene kao nove teorije rasta. Analiza se proširuje analizom razvoja u teorijama regionalne ekonomije i ruralnih studija, sistematizuje klasifikaciju ovih teorija prema teoretičarima regionalne ekonomije. Ograđujući se od svake podele pojedinačno kao najprikladnije i najprihvatljivije, tretiraju se posebno $i$ u istorijskom kontekstu kako bi se omeđio vremenski period u kome nastaju savremene teorije koje tretiraju lokalni nivo sa svim razvojnim problemima koji ga karakterišu. Ističe se pojava tzv. teorija razvoja koje sprovodi ruralna/lokalna zajednica (The community-led rural development theory). koju često nazivaju teorijom razvoja zajednice (Community development theory), ili koju obeležavaju kao "partnerski pristup odozdo na gore " (bottom-up partnership approach). Analiza teorija razvoja, ističe da mešoviti egzogeno-endogeni pristup razvoju povezuje ruralni/lokalni razvoj sa procesom globalizacije najviše zahvaljujući brzim tehnološkim promenama $u$ informacionom i sektoru komunikacija.

Ključne reči : ekonomski rast, lokalni ekonomski rasti i razvoj, egzogeni, endogeni $i$ egzogeno - endogeni razvoj.

4 Docent, dr Bahrija Kačar, Državni univerzitet u Novom Pazaru, Departman za ekonomske nauke, Ulica Vuka Karadžića bb, 36300 Novi Pazar, Srbija, Telefon: +381 62333808 E-mail: bahrijakacarnp@yahoo.com

5 Državni Univerzitet u Novom Pazaru, Departman za hemisko-tehnološke nauke, studijski program poljoprivredna proizvodnja, Vuka Karadžića br, 36300 Novi Pazar, Srbija, E-mail: jasminacuric65@gmail.com

6 Mr Selma Ikić, saradnik, Kancelarija za lokalni ekonmski razvoj, Gradska uprava grada Novog Pazara, Stevana Nemanje 2, 36300 Novi Pazar, Srbija, Phone: +381 62488740, E-mail: : selma.ikic@novipazar.org.rs 